\title{
Soviet Diplomacy in Norway and Sweden in the Interwar Years: The Role of Alexandra Kollontai
}

Åsmund Egge (University of Os/o)

\section{INTRODUCTION}

T $\mathrm{n}$ this article, I shall take a look at Soviet diplomacy in Norway and Sweden in the interwar years and try to assess the role of Alexandra Kollontai in the Soviet-Norwegian and Soviet-Swedish relationship during this period. ${ }^{1}$ Kollontai was the leader (polnomochnyi predstavitel', or polpred, for short) of the Soviet diplomatic representation in Norway from $1923^{2}$ to 1930 (except for a short stay in Mexico in 1926-1927) and in Sweden from 1930 to 1945 (from 1943 as ambassador). She is regarded as the first female diplomat in modern times.

Alexandra Kollontai had no diplomatic experience before her appointment as an adviser to the Soviet trade delegation in Norway in the autumn of 1922. She was, however, well qualified for such a job. She had a good education, spoke several languages, and was well acquainted with appearing at international forums and dealing with foreigners. A special advantage for her work in Norway was her knowledge of the country and of many Norwegians from her residence in Norway during the First World War.

Let us start by asking: How did Kollontai perform her work as a diplomat in Norway and Sweden? What was her personal contribution to the relation between the Soviet Union and these two countries? How was she received in these countries and what was her relationship to important political

\footnotetext{
1 I will not deal with Kollontai's important role as an intermediary between the Soviet Union and Finland during the Winter War and the Continuation War. This would call for a separate article.

2 She arrived in Norway in October 1922, as an adviser to the Soviet trade mission.
} 
circles-especially the labor movement? Was there a difference in Soviet diplomacy in Norway and Sweden in the interwar years and, if so, can it be related to the personal influence of Kollontai?

Soviet foreign policy was, almost from the start, a dualistic project. On the one hand, there was the world revolutionary objective, represented by the establishment of the Communist International (or Comintern, for short); on the other, Soviet Russia needed to break out of its international isolation and form normal diplomatic relationships with other states. This dualism was, of course, self-contradictory. Russia was attempting to have good relations with foreign governments while at the same time working to topple these governments through communist revolutions.

\section{ALEXANDRA KOLLONTAI: BETWEEN DIPLOMACY AND PARTY IN NORWAY}

This problematic dualism soon became apparent in Norway. ${ }^{3}$ The Norwegian Labor Party_Det norske Arbeiderparti (DnA) — joined the Comintern in June 1919. The DnA was among the few majority socialist parties in Europe to sign up with the Comintern, and the only majority party to accept the famous, or infamous, twenty-one conditions for membership in the Comintern, adopted at the Comintern's second congress in the summer of $1920 .{ }^{4}$ However, the "Moscow Theses," as they were called in Norway, were soon the object of controversy in the party, and in the end led to a split in November 1923, and the foundation of the Communist Party of Norway (NKP) as the Norwegian "section" of the Comintern. 5

Kollontai's role as a diplomat called for exercising caution in dealing with intra-party affairs. She had been duly instructed by Foreign Commissar Georgii Chicherin in a letter in which he underscored "the sharp distinction, because of the historical situation, we have to make between state and party work." ${ }^{6}$ She was cautious from the start. In an interview to a Norwegian

3 About Alexandra Kollontai and the Norwegian labor movement, see Åsmund Egge, "Aleksandra Kollontaj og norsk arbeiderbevegelse," in Yngvild Sørbye, ed. Revolusjon, kjarlighet, diplomati. Aleksandra Kollontaj og Norden (Oslo: Unipub, 2008), 55-81; Åsmund Egge, Sven G. Holtsmark, and Aleksej Komarov, introduction to Diplomatiske nedtegnelser 1922-1930, by Aleksandra M. Kollontaj (Oslo: Res Publica, 2015), 15-37.

4 The DnA was the biggest of the parties in the labor movement.

5 Åsmund Egge, Komintern og krisen i Det norske arbeiderparti (Oslo: Universitetsforlaget, 1995).

6 Chicherin to Kollontai, November 4, 1922. AVPRF, f. 04, op. 30, p. 199, d. 52327, 11. 32-33. Published in Sovetsko-Norvezhskie otnosheniia 1917-1955: Sbornik dokumentov 
newspaper just after her arrival in the country, when asked about the forthcoming Comintern congress, she dismissed the question: "Not a word about the Comintern ..." All the same, in her diplomatic notes she asked herself whether it could be possible to stay away from the local communists: "Don't we have to correct them when they make mistakes?"7

In connection with an extended central committee meeting of the DnA in January 1923, the leader of the Russian trade delegation at the time, Yakov Surits, and Kollontai were instructed to keep a distance from the struggle in the party, but all the same influence the leaders of the party through private conversations so that the party should leave behind "the dead end of these harmful debates." ${ }^{8}$ Later, Kollontai also had political discussions with the party leaders, especially from the wing loyal to the Comintern. ${ }^{9}$ So, there was a certain overlapping between strictly diplomatic work and party affairs, after all.

Kollontai was critical to the policy of the Comintern toward the Norwegian party and tried, through her secretary Marcel Body, to influence the Comintern leadership to have patience with the Norwegians in order to avoid a party split. ${ }^{10}$ She was concerned that the implementation of strict Comintern policy would hurt her work for a Norwegian de jure recognition of the Soviet government. After the party divided, she expressed her anger:

To my great sorrow I cannot fail to remark that the [Norwegian] party, which until now has had great political weight, and maybe was the only Communist party that could have played a role as an essential political factor in the issue of the recognition of Russia, is now weakened by the split. The timing chosen for the split is extremely unfortunate for us.

(Moscow: ELIA-ART-O, 1997), doc. 60. Norwegian translation in Sven G. Holtsmark (ed.), Norge og Sovjetunionen 1917-1955 (Oslo: J. W. Cappelens forlag, 1995), doc. 60. Translation into English by the author.

7 Aleksandra Kollontaj, Diplomatiske nedtegnelser 1922-1930 (Oslo: Res publica 2015), 118 (October 14, 1922) and 122 (October 15, 1922). The interview was published in SocialDemokraten, October 16, 1922. All quotes from Kollontai's diplomatic notes are translated by the author.

8 Ibid., 168 (March 3, 1923).

9 Such as ibid., 288-290.

10 Egge, Komintern og krisen, 91-94, 103-104. Body's letters are published (in Norwegian translation) in Åsmund Egge and Vadim Roginskii (eds.), Komintern og Norge. DNA-perioden 1919-1923. En dokumentasjon (Oslo: Unipub, 2006), doc. 288, 312. The originals are in RGASPI, f.495, op.18, d.171a, 11.91-94 (in French) and f. 495, op. 18, d.171a, 11.106-109 (in Russian). 
I am extremely surprised that the Comintern did not take into account the political situation and used excessive haste in forcing through the split, obviously without consideration for, or taking into account of, the extent to which what has happened makes our foremost task difficult. ${ }^{11}$

Even after the split of the Norwegian Labor Party in 1923, the labor movement remained for many years more sympathetic to the Soviet Union than was the case in other Western European labor movements. ${ }^{12}$ This was the case not only for the Communist Party of Norway, which was rapidly weakening, but also for the much larger, and non-Comintern, Norwegian Labor Party.

Broad sympathy for the Soviet project led to the DnA and NKP cooperating with Soviet diplomats. ${ }^{13}$ Kollontai and other Soviet diplomats gained access to Norwegian classified information through DnA and NKP members of Parliament (the Storting). Furthermore, there was coordination between the diplomats and their Norwegian "friends" on foreign policy matters, mostly relating to Soviet-Norwegian relations. Soviet diplomats influenced the Norwegian left's stance on Norwegian domestic policy issues. This was, however, a two-way activity, as the Norwegian left sometimes also tried to influence Soviet policy toward Norway.

During the infighting within the DnA before it split in 1923, the Comintern-friendly faction tried to get help from the Comintern and also tried to use the Soviet trade mission as an intermediary when asking for financial assistance. According to a police report, Kollontai allegedly expressed some frustration with nagging from the leader of the Comintern-friendly faction. ${ }^{14}$

On a personal level, and maybe even politically, Kollontai was closer to the representatives of the Labor Party than to the Communist Party. Her closest friends among the Norwegians were Martin Tranmæl, the de facto leader of the Labor Party, and Rachel Grepp, the widow of the late Labor Party chairman, Kyrre Grepp. An indication of her closeness to and trust in the Labor Party is a letter from Kollontai to Rachel Grepp, written in December 1930,

11 Kollontai to Maxim Litvinov, November 9, 1923. AVPRF, f. 04, op. 30, p. 199, d. 52336, 11. 86-89. Here quoted from Åsmund Egge and Sven G. Holtsmark, "Soviet Diplomacy and the Norwegian Left, 1921-1939," in Caution \& Compliance. Norwegian-Russian Diplomatic Relations 1814-2014, ed. Kari Aga Myklebost and Stian Bones (Stamsund: Orkana, 2012), 109.

12 Åsmund Egge, "Fra revolusjonsbegeistring til brobygging-Moskva i norsk arbeiderbevegelse 1917-1991,” Mediehistorisk Tidsskrift 28, no. 2 (2017): 16-27.

13 Egge and Holtsmark, "Soviet Diplomacy," 101-112.

14 Martin Nag, Kollontaj i Norge (Oslo: Solum, 1981), 44. 
shortly after Kollontai's transfer as a polpred to Stockholm. In the letter, she voices concern about the fate of her archive in case of her death. She was afraid that someone would get hold of her papers and "make bad use of them or destroy them." To the Soviet Union's Revolutionary Museum, "you may give only printed books and articles, in no case manuscripts [emphasis in the original]." These should be taken care of by some of her close friends. At the end of the letter, she even indicates that the Norwegian Labor Party might take care of her archive: "Perhaps 'Arbeiderparti' [DnA] would take all of my material under the Arbeiderparti's care?" 15

\section{KOLLONTAI AS A DIPLOMAT IN NORWAY}

Less than a year before Kollontai came to Norway as an advisor to the trade delegation, she had asked for a visa to visit Norway. However, the chief of the Norwegian security police regarded her as a "one of the most dedicated and prominent (ivrigste og fremmeligste) revolutionaries" and advised most definitely against giving her a visa. ${ }^{16}$ This was in 1921, at the peak of the fear of revolution in Norway. She eventually got a visa on certain conditions, but the visit was not pulled off.

At her arrival in October 1922, she was put under police surveillance. But as Kollontai lived a rather obscure life during her first months in Norway, there was not much to be reported. Her reception in the press followed political lines. The labor press was friendly; the bourgeois papers were negatively disposed towards her. It was reported that Kollontai had complained about the unfriendly attitude from the bourgeois press against herself and the Soviet government. ${ }^{17}$

As mentioned, in spite of her lack of experience in diplomatic work Kollontai had certain advantages as a diplomat in Norway. Her good education, her knowledge of several languages - she even spoke rather good Norwegian - and her acquaintance with Norway and many Norwegians from her earlier residence in Norway gave her an excellent starting point. Her good contacts with leading members of a strong Labor Party that was better disposed towards the Soviet Union than probably any other social democratic

15 Kollontai to Grepp, December 19, 1930. The Labour Movement's Archive and Library (Oslo), Ark-2754 Rachel Grepp, boks F 7 Brev og manuskripter, Mappe 1, Aleksandra Kollontaj-Brev.

16 Nag, Kollontaj i Norge, 42-43.

17 Ibid., 48. 
party, gave her a unique insight into the conditions prevailing in Norway. In addition to Tranmæl, Grepp, and other friends on the left, she also became personally acquainted with political leaders from the bourgeois parties, most importantly Johan Ludwig Mowinckel, leader of the liberal party and prime minister during the greater part of Kollontai's diplomatic residence in Norway. In her work for the normalization of relations between Norway and the Soviet Union, Kollontai also established contacts far outside purely political milieus.

Kollontai's broad connections, including her personal friendship with some of the leading politicians and her active and successful diplomatic work, may have given her an influence unusual for a diplomat. This may be illustrated by the following incident (for which we, admittedly, only have Kollontai's word). At the beginning of 1930, the Storting was about to discuss a proposal from the government about raising duties on imported wood. At this time, a considerable quantity of wood for processing paper at the Borregaard paper mill was imported from the Soviet Union. Borregaard's director contacted Kollontai to ask her to influence the government: "Madam Kollontai, ask the government to postpone the question about raising the customs on wood at least for a year. This will be advantageous for both you and us. And you have such an influence on the government that your 'wish' counts more than an inquiry from a Norwegian industrialist." 18

Kollontai's standing with the general public in Norway changed remarkably in a short time. From being looked upon as a suspicious and despicable Bolshevik among bourgeois society, she became respected and even popular. When she returned to Norway from Mexico in 1927, she was welcomed even in the conservative newspapers. S. M. Mirnyi, who worked as Kollontai's secretary after her return, later remarked — maybe with a little exaggeration —on Kollontai's popularity during her last period as polpred in Norway: "To say that Kollontai was popular in Norway — that is to say too little. She was loved." ${ }^{19}$

Kollontai's diplomatic activity in Norway was characterized by a limited amount of cases. The main question during the first years was the Norwegian de jure recognition of the Soviet Union, which was solved in February 1924. ${ }^{20}$

18 Kollontaj, Diplomatiske nedtegnelser, 667 (February 18, 1930), Kollontai's rendering of the director's words.

19 S. M. Mirnyi, "Aleksandra Kollontai: kak ia ee pomniu," in Severnaia Evropa. Problemy istorii, vol. 5, ed. O. V. Chernysheva (Moscow: Nauka, 2005), 293. English translation by the author.

20 See, for example, Gyrid Celius, "Norwegian-Soviet relations, 1920-1924: Negotiations on the Spitsbergen question and de jure recognition of the Soviet Government," in Myklebost and Bones, Caution and Compliance, 137-148. 
Another problem that absorbed a lot of Kollontai's time concerned the consequences for Norwegian seal hunters of the Soviet government's extension of its territorial borders in the North, which implied that Franz Josef's Land and other islands in the Arctic Ocean became Soviet territory. ${ }^{21}$ Kollontai was also involved with commercial and economic affairs, not least negotiations about establishing trade agreements, especially about the export of fish from Norway to Russia. ${ }^{22}$ These efforts also had political implications as the outcome of the export negotiations would influence the Norwegian fishermen's attitude to the Soviet Union-and to the Norwegian communists. ${ }^{23}$ During the last years of Kollontai's activity in Norway, protracted negotiations were in progress about a Soviet-Norwegian non-aggression treaty. The Norwegian government insisted instead on the establishment of an arbitration board, and the negotiations came to nothing. ${ }^{24}$

There is also a reason to emphasize Kollontai's role in establishing cultural contacts between Norway and the Soviet Union. Especially in her last years in Norway, she developed a broad network of contacts with Norwegian writers and artists. ${ }^{25}$

In her diplomatic work, Kollontai was active in establishing contacts and in promoting initiatives that could strengthen the prestige of the Soviet Union. This made it possible for her to write copious and well-informed reports to the People's Commissariat for Foreign Affairs (NKID) in Moscow. However, in accordance with her instructions from Chicherin, she showed caution when it came to taking independent initiative in politically sensitive matters. I. M. Diakonov, who as a boy was living in Oslo where his father was working in the Soviet representation, remembers his father saying that Kollontai was not characterized by boldness in her work: she feared making independent

21 See, for example, Sven G. Holtsmark (ed.), Naboer i frykt og forventning. Norge og Russland 1917-2014 (Oslo: Pax, 2015), 93-111.

22 A. V. Repnevskii, SSSR-Norvegiia: Ekonomicheskie otnosheniia mezhvoennogo dvadtsatiletiia (Arkhangelsk: Izdatel'stvo Pomorskogo gosudarstvennogo universiteta, 1998), 109-168.

23 Kollontai was keenly aware of this. In 1933, from her viewpoint in Stockholm, she criticized the Soviet policy towards Norway: "Rozengolts has made the mistake of not buying fish from them [the Norwegians] this year. It would have been worthwhile to pay four million crowns to keep the sympathy for us among the coast population." Aleksandra Kollontaj, Aleksandra Kollontajs dagböcker 1930-1940 (Stockholm: Albert Bonniers förlag, 2008), 301 (March 27, 1933).

24 Sven G. Holtsmark, “A. M. Kollontaj og forholdet Norge-Sovjetunionen,” in Sørbye, Revolusjon, 124-127.

25 See, among others, Daniela Büchten, "Kunst og politikk. Diplomaten Aleksandra Kollontaj som kulturformidler," in Sørbye, Revolusjon, 287-316. 
decisions. ${ }^{26}$ Diakonov attaches this to her need to be extra cautious because of her former role as an oppositionist-she had been one of the leaders of the so-called “Workers' opposition” before her assignment as a diplomat. This theory have something to recommend it. But another reason might be her own experience in not having the necessary support from Moscow in her diplomatic work. In connection with the Norwegian de jure recognition of the Soviet government in February 1924, a joint pronouncement between Kollontai and the Norwegian foreign minister was drawn up. This pronouncement contained a formulation that could be interpreted as if Norway was promised most-favored-nation treatment in the future trade- and shipping agreement that would be worked out between the two countries. The text of the pronouncement had not received clearance from the NKID, and Kollontai received a strict reprimand that she had exceeded her instructions. She was then forced into a humiliating and embarrassing retreat. ${ }^{27}$

However, Kollontai did not flinch from freely expressing her opinions to her superiors, and she made independent assessments in a lot of cases. For example, Kollontai played a personal and decisive role in the NorwegianSoviet negotiations about Norwegian de jure recognition of the Soviet government. The final agreement, which stated the Soviet government's recognition of Norwegian supremacy over the Spitsbergen islands, was in fact the work of Kollontai. Chicherin at first failed to understand Kollontai's reasoning-that Norway could be elicited to diplomatic recognition of the Soviet government through Soviet accommodation in the Spitsbergen question. But, finally, Kollontai's arguments won the day. 28

The reason why Kollontai and the Soviet government during the autumn of 1923 attached such importance to negotiations about diplomatic recognition de jure with a small country like Norway was that Norway appeared to be the first country in Western Europe likely to recognize the Soviet government. International recognition was the Soviet government's foreign policy priority at this time, and recognition even from a small country would strengthen its negotiating position with the great powers. However, the Norwegian government

26 V. A. Shishkin, Stanovlenie vneshnei politiki poslerevoliutsionnoi Rossii (1917-1930 gody) $i$ kapitalisticheskii mir (St. Petersburg: Dmitrii Bulanin, 2002), 10.

27 Celius, "Norwegian-Soviet Relations," 146. See also Holtsmark, "A.M. Kollontaj," 106-107. Kollontai herself deals with this question in her diplomatic notes, see Kollontaj, Diplomatiske nedtegnelser, 325-331.

28 Egge, Holtsmark, and Komarov, Introduction, 39-42. Celius, "Norwegian-Soviet Relations," $142-148$. 
did not dare to defy Great Britain and the other great powers in the question of recognition. To Kollontai's great disappointment, both Italy and Great Britain recognized the Soviet government before Norway did.

\section{SOVIET DIPLOMATIC ACTIVITY IN NORWAY IN THE 1930s}

The Soviet diplomats that followed never had the same influence and authority that Kollontai had enjoyed during her time in Norway. Admittedly, they also from time to time received confidential information from sources in the NKP and DnA. But the NKP soon became an unimportant factor in Norwegian politics, and after 1930 had no members in the Storting. The fact that later diplomats lacked Kollontai's extensive network of contacts was probably more significant. ${ }^{29}$

The growing Stalinization in the 1930s, and the Great Terror especially, influenced the work of Soviet diplomats. In Norway, Kollontai's successors had less scope of action and showed less active reporting about the Norwegian state of affairs. Her first successor, Alexander A. Bekzadian, continued to write extensive reports on a broad spectrum of themes regarding Norwegian politics and Norwegian society, just as Kollontai had done. However, once he left Norway in 1934, Soviet diplomatic reports became of limited breadth and contained little of value. After 1937, political reports to Moscow ceased almost completely. ${ }^{30}$

\section{SOVIET DIPLOMATIC ACTIVITY IN SWEDEN IN THE 1920s}

With the New Economic Policy from 1921, the Soviet foreign policy changed from placing hope in revolutionary upheaval in the Western world to establishing normal diplomatic relations with other states - in particular, the greater Western European powers. During the first years after the October Revolution, the Russians regarded Stockholm as one of the main centers for Soviet activity toward the capitalist West. ${ }^{31}$ In May 1920, Sweden was the first country to conclude a contract with Soviet Russia for the delivery of industrial products, the so-called "Krasin agreement." This was a purely commercial affair, and the

29 Holtsmark, “A. M. Kollontaj," 118.

30 Holtsmark, Naboer, 27-28.

31 See, for example, Aleksander Kan, Hemmabolsjevikerna. Den svenska socialdemokratin, ryska bolsjeviker och mensjeviker under världskriget och revolutionsåren 1914-1920 (Stockholm: Carlsson bokförlag, 2005), 244-249. 
Swedish authorities for a long time repeatedly refused to accept a politically trusted person as the head of the Soviet trade delegation. Even more persistently, the Swedish government refused to accept any political role whatsoever for the trade delegation's leader. The Swedes wanted to avoid doing anything that might be interpreted as a de facto recognition of the Soviet government. The answer from the Soviet government was to insist on a political regulation of the Swedish-Soviet relationship before any economic advantages for the Swedish trade and industry could be taken into account. ${ }^{32}$

In September 1921, a trade agreement between Norway and Soviet Russia was reached. This implied a de facto recognition of the Soviet government on the part of Norway. Shortly afterwards, a social democratic government led by Hjalmar Branting assumed power in Sweden. A parliamentary commission was set up to consider the question of a Swedish-Russian trade agreement, and in April 1922 the government put a proposal for such an agreement before the parliament (the Riksdag). The proposal was rejected by both chambers in the Riksdag. ${ }^{33}$ The traditional anti-Russian attitude among Swedish conservatives was too strong for a de facto recognition at this stage. ${ }^{34}$ The conditions for diplomatic success in dealing with Sweden were clearly more difficult than they were in Norway. The first Russian envoys, Platon Kerzhentsev and Valerian Osinskii, got a rather chilly reception from the Swedish authorities. ${ }^{35}$

In Moscow, the answer to the Swedish rejection of the trade agreement was a cancellation of the "Krasin agreement" and the introduction of an economic boycott of Sweden. ${ }^{36}$ This was all the more easy now, since the Treaty of Rapallo with Germany made it possible — and even desirable — to shift economic focus from Sweden to Germany.

The economic relations between Sweden and Russia were far more important than those between Norway and Russia. For instance, Swedish exports to Soviet Russia were at this time relatively greater than that of any

32 Helene Carlbäck-Isotalo, Att byta erkännande mot handel. Svensk-ryska förhandlingar 1921-1924 (Uppsala: Studia historica Upsaliensia, 1997), passim. For a short exposition of the SovietSwedish relations in the beginning of the 1920s, see Erik Lönnroth, Den svenska utrikespolitikens historia, vol. V, 1919-1939 (Stockholm: P. A. Norstedt \& Söners förlag, 1954), 70-75.

33 Carlbäck-Isotalo, Att byta erkännande, 175-184.

34 About the Swedish elites' traditional attitude to Russia before the war, see Gunnar Åselius, The "Russian Menace" to Sweden. The Belief System of a Small Power Security Élite in the Age of Imperialism (Stockholm: Almqvist \& Wiksell, 1994).

35 About Kerzhentsev and Osinskii, see Carlbäck-Isotala, Att byta erkännande, 43-44, 216217 and passim.

36 Ibid., 184. 
other country. ${ }^{37}$ At the beginning of 1923, the Soviets found it advantageous to cancel the economic boycott. Preliminary talks had already been initiated, but the Swedish attitude became cold after a new conservative government came to power in April 1923. ${ }^{38}$

As mentioned, Kollontai benefited from access to sensitive information through her contacts in the Norwegian labor movement. We know much less about the connections between the Soviet representatives in Stockholm and the Swedish left in the 1920s. Karl Kilbom, one of the most prominent leaders in the Swedish labor movement, was a good friend of Osinskii, who until 1924 was the Soviet representative in Sweden. Osinskii may have received confidential information from Kilbom, who however strongly denies this. ${ }^{39}$

\section{KOLLONTAI'S TRANSFER TO SWEDEN}

On 21 April 1930, Kollontai received a telegram from Moscow which informed her that the Politburo had appointed her as provisional chargé d'affaires in Sweden. ${ }^{40}$ The background for the appointment was trouble at the representation in Stockholm. A member of the representation had defected and another had disappeared. The polpred himself was seriously ill and had to be replaced.

This appointment was not Kollontai's wish. She wanted most of all to leave diplomatic work and return to the Soviet Union working as a writer. ${ }^{41}$ But if that was not possible, she preferred to stay in Norway. According to her diplomatic notes, she had already written, begging, to the party: "I ask you urgently not under any circumstances to appoint me to Sweden." 42 But her plea was to no avail.

37 Ibid., 178.

38 Ibid., 208.

39 Karl Kilbom, I hemligt uppdrag. Ur mitt livs äventyr II (Stockholm: Tiden, 1954), 281-282.

40 Kollontaj, Diplomatiske nedtegnelser, 680-681 (April 21, 1930). The Politburo had decided the day before to appoint Kollontai to this provisional post while she kept her office in Norway.

41 For example: "I want, I want to go home!" See Kollontaj, Aleksandra Kollontajs dagböcker, 242 (end of March 1932). Already in 1925 Kollontai had in a letter to deputy foreign commissar, Maxim Litvinov, asked to be relieved from her post as polpred in Norway. (Anna M. Itkina, Revoliutsioner, tribun, diplomat [Moscow: Politizdat, 1970]). She wanted to "again become a free writer without official rank." (Kollontaj to Fredrik Ström, July 24, 1925, in Aleksandra Kollontaj, "Kära kamrat: allra käraste vän," ed. Britta Stövling [Stockholm: Gidlund, 1977], 30).

42 Kollontaj, Diplomatiske nedtegnelser, 680 (April 1930). Also, after having been permanently stationed in Sweden, she tried to get away, in the summer of 1931 as an envoy to France, in 
Kollontai's earlier experiences with Sweden were not especially positive. Admittedly, in 1912 she completed a successful lecture tour in Sweden. But when she went from Berlin to Stockholm, after the outbreak of war in 1914, she was soon arrested and permanently expelled from Sweden. In February 1918, she was assigned to lead a Soviet delegation to prepare an international socialist conference in Petrograd. The delegation tried to reach Stockholm but did not get any further than Mariehamn on the Åland islands, which had recently been occupied by Swedish troops. Kollontai was then forced to return to Åbo in Finland. ${ }^{43}$

Kollontai's first and most important problem as the new polpred in Stockholm was to reestablish order in the representation, a task in which she succeeded. Secondly, she had to improve the image of her mission in the eyes of the Swedish authorities and public. This was not an easy task. Kollontai's predecessor had been looked upon with suspicion and was more or less ostracized both by the diplomatic corps and Stockholm society. ${ }^{44}$ Her reception in Sweden was very cool. In a letter to her friend, Zoia Shadurskaia, she writes:

It is not an easy task I have got-the atmosphere of enmity against the Union and against everybody from the representation is rude and explicit. When I and Pina walk through the lobby, the haughty and smug Swedes who had sat down in the armchairs, send us so openly hostile looks that I don't remember anything similar since Berlin during the first days of the war against Russia (1914). Our former "friends" among the social democrats keep plainly clear, they don't visit [us] and answer curtly on the telephone. ${ }^{45}$

In another letter to Zoia, she again complains about the Swedes:

Do you remember Pushkin's words: "To annoy the arrogant neighbor" etc. The Swedes are still arrogantly self-satisfied. And they still remember Poltava. And they remember how they lost Finland. "The Russian bear" - whether he wears the crown of the tsar or a five-toothed star-is all the same "dangerous." There is nothing like that in Norway. ${ }^{46}$

1934 to Spain, and in 1935 to Belgium (Oleg Ken, Aleksandr Rupasov, and Lenart Samuelson, Shvetsiia v politike Moskvy 1930-1950-e gody [Moscow: ROSSPEN, 2005], 54-55, note 50).

43 Kan, Hemmabolsjevikerna, 57, 298-301.

44 Kaare Hauge, Alexandra Mikhailovna Kollontai: The Scandinavian Period, 1922-1945 (Doct. diss., Minneapolis, MN: University of Minnesota, 1971), 156-158.

45 Kollontaj, Diplomatiske nedtegnelser, 698 (April 27, 1930).

46 Ibid., 702-703 (May 1, 1930). Also later she wrote about "this ocean of hostility" 
In her diplomatic notes, Kollontai often makes comparisons between Norway and Sweden, and there is no doubt about where her sympathies are. The Swedes were more formal and more monarchist. She complains about a general lack of humor- "especially in Sweden, the Norwegians are more cheerful." ${ }^{47}$ In a letter to Mowinckel, her Norwegian friend, she writes that she is missing Norway. She "believes that there is more spiritual contact between Norwegians and Russians."

\section{KOLLONTAI'S DIPLOMATIC WORK IN SWEDEN IN THE 1930s}

There was a significant difference between the Soviet Union's relationship with Sweden compared to its relationship with Norway, both politically and economically. Sweden was a traditional enemy; Norway and Russia had never waged war. Sweden was, like Soviet Russia, a Baltic power; Norway was not. Sweden was much more important economically for the Soviet Union, compared to Norway. ${ }^{49}$

However, in the interwar years there emerged more fields of potential conflict between Norway and the Soviet Union. There were disputes about fishing rights and territorial limits at sea, and there was potential conflict over Norwegian jurisdiction over the Spitsbergen islands. The Soviet Union had no comparable areas of conflict with Sweden. ${ }^{50}$ Furthermore, the economic systems of Sweden and the Soviet Union were highly complementary with regard to trade and industry. Swedish society was transparent and predictable, and therefore gave the Soviets no ground for fear of dangerous surprises. Finally, Sweden had no part in any anti-Soviet alliances or groups, and consequently was maybe in a unique position among other European states in the immediate vicinity of the Soviet Union.

Therefore, objectively the circumstances would seem to be good for the Soviet-Swedish cooperation, economically as well as politically. This was much more the case after the Swedish Social Democratic Party came to power in September 1932. But the Soviet leaders were incapable of exploiting this historical opportunity. This was during the period of the most intense Soviet hostility to European social democrats. ${ }^{51}$ And the international situation made

and that "the atmosphere around us is gloomy, distant and stifling" (ibid., 773, 775 [November 23, 1930]).

47 Kollontaj, Aleksandra Kollontajs dagböcker, 163, 273.

48 Kollontai to Mowincel, November 19, 1930, in Nag, Kollontaj i Norge, 32.

49 On the other hand, Russia was not as important economically for Sweden as it was for Norway.

50 In the following I am leaning on Ken et al., Shvetsiia, esp. 151-181.

51 About this so-called "third period," see, for example, Kevin McDermott and Jeremy Agnew, 
it urgent for the Soviets to give most of their attention to great power politics rather than smaller states. This was noted by Kollontai. ${ }^{52}$

Kollontai had a realistic understanding of what she could accomplish and of the importance of economic relations between the two countries. At the beginning of 1932 she wrote about her mission:

My task as envoy is to strengthen Sweden's friendly relations with us, to strengthen our prestige and our influence. For this to happen, there must be a firm economic foundation.... The closer the two countries' interests regarding economy and trade are united, the more realistic will be their community and common acting towards third parties.... I do not hope to make Sweden an active friend but to get the Swedes to reckon with the benefit of friendly relations with the Union and to remain neutral in case of pressure from third parties. ${ }^{53}$

However, Kollontai was not happy dealing with trade questions. In Norway, it had been fish; in Sweden, it was wood. The wood market was the only field of conflict between the two countries. The Swedes and the Finns criticized the Russians for dumping wood on the world market - wood produced by lowpaid Soviet workers or even slave workers. To mitigate this critique, Kollontai proposed integrating the Soviet wood export monopoly as a third part in the Swedish-Finnish cartel of wood-producing enterprises. ${ }^{54}$ In 1931 and 1932, negotiations with Sweden and Finland about export quotas dragged on for months and without result. Kollontai joked that it would be easier to put on gramophone records where the parties' arguments were recorded. ${ }^{55}$

Another frustrating experience was the negotiations in 1934 concerning a state loan from Sweden to the Soviet Union. ${ }^{56}$ Such a loan was not only economically important. It was also politically important in that it was the first

The Comintern. A History of International Communism from Lenin to Stalin (London: MacMillan, 1996), ch. 3.

52 Kollontaj, Aleksandra Kollontajs dagböcker, 413 (October 3, 1934), 425 (end of December 1934). The NKID's dealing with Scandinavian affairs was transferred from a separate department to a department comprising Western Europe, America, and the British dominions. Cf. Ken et al., Shvetsiia, 42.

53 Kollontaj, Aleksandra Kollontajs dagböcker, 230 (January 21, 1932).

54 Krister Wahlbäck, "Finland-en politisk nervknut. Aleksandra Kollontaj i Sverige 19301945," in Sørbye, Revolusjon, 174.

55 Kollontaj, Aleksandra Kollontajs dagböcker, 209.

56 Ibid., 339-387; Ken et al., Shvetsiia, 50-55; Wahlbäck, “Finland," 174-177. 
state loan the Soviet Union negotiated with a foreign country, that is, not only financial credits connected to specific trade agreements. Kollontai hoped that the loan would strengthen the influence of the Soviet Union in Sweden and that it would also establish a precedent to the benefit of the Union. ${ }^{57}$

The loan agreement was signed in March 1934, but had to be approved by the Swedish parliament, the Riksdag. Now began a fierce press campaign by conservatives in Sweden against the agreement. The political situation in the Riksdag was uncertain. The minority Social Democratic government was dependent on support from the Farmers' Party. The Soviets now became afraid of the loss of prestige for the Soviet Union in case of a negative vote in the Riksdag. When it became probable that the Riksdag would turn down the agreement, the Russians forestalled the Swedes by refusing to ratify the loan. In this way, the agreement would not come to a vote in the Riksdag. ${ }^{58}$

In spite of some derogatory characterizations of the Social Democrats in Kollontai's reports to the NKID, she was eagerly cultivating connections with Social Democrats, especially from the left wing of the party. One example is her relationship with Gustav Möller, a government minister. His information about the views of other members of the government, and his evaluation of the loyalty of the Swedish military command, which he shared with Kollontai, often had an extremely confidential character. ${ }^{59}$ She had also close contact with the lawyer and politician Georg Branting, son of the former Social Democrat leader and prime minister Hjalmar Branting. Georg Branting worked for a time as a lawyer for the Soviet representation. His political views were close to the communists'. Kollontai once commented that he had become "quite Bolshevik." 60 However, her connections with Swedish Social Democrats were never as close and confidential as her relations with politicians in the Norwegian Labor Party.

Kollontai also had contact with leading Swedish communists, especially with Sven Linderot and his wife. When Kollontai arrived in Sweden, the Communist Party of Sweden had recently split in two, and the situation for Comintern loyalists was extremely difficult. ${ }^{61}$ Kollontai was very worried, but

57 Kollontaj, Aleksandra Kollontajs dagböcker, 355 (January 12, 1934).

58 In her diplomatic notes Kollontai is incorrectly taking credit for the idea of the forestalling of the Swedes. Ken et al., Shvetsiia, 53, note 45.

59 Ibid., 152-153.

60 Kollontai to Z. L. Shadurskaia, October 17, 1937. Here quoted from Ken et al., Shvetsiia, 154.

61 About the Communist Party of Sweden, see, for example, Åsmund Egge and Svend Rybner (eds.), Red Star in the North. Communism in the Nordic Countries (Stamsund: Orkana, 2015). 
wrote that she "cannot, and must not, meddle in the affairs of our friendseven though it is irritating to see." 62

While Kollontai's personal diplomacy helped to win friends, her efforts to influence the left in Sweden were only noticeable during a short period in the middle of the 1930s. At this time, the Soviet attitude to the Social Democrats changed, from regarding them as "social fascists" to including them in the policy of "people's front." In the foreign policy field, the collective security line had a lively flowering. In 1935, a Swedish-Soviet friendship organization was reestablished. ${ }^{63}$ A year later, Kollontai reported a noticeable strengthening of sympathy with the Soviet Union "among broad circles of not only Sweden's radical intelligentsia but also among scientists, professors, representatives of the liberal arts, etc." ${ }^{64}$ Kollontai explained that this was partly due to growing fears about the Nazi regime in Germany and partly because of a closer and more direct knowledge about Soviet reality. However, political Sweden kept a distance. Swedish politicians, even Kollontai's old friends on the left, refused to join the new friendship organization. ${ }^{65}$ And in the late 1930s, "cultural expansion" and the work required to present the Soviet Union as a pillar of peace and democracy were sparse. ${ }^{66}$ This had to do with the general political atmosphere and the consequences of repression in the government departments that dealt with international contacts.

The Great Terror (1937-1938) was an extremely difficult period for Kollontai. She suffered as old friends disappeared - including her former lover, Alexander Shliapnikov, and her former husband, Pavel Dybenko. She feared for her own life. Before both of her visits to Moscow during these years, she wrote farewell letters to her Swedish friend, Ada Nilsson, asking her-as she had earlier asked Rachel Grepp - to take care of her personal papers. ${ }^{67}$ Why Kollontai was spared from the terror, one can only speculate. She had taken a clear stand against the opposition to Stalin. ${ }^{68}$ She was obviously useful as a Soviet diplomat in Scandinavia. Stalin probably found her harmless. Her old friend Zeth Höglund in his memoirs called her "politically Stalin's soft slave."69

62 Kollontaj, Aleksandra Kollontajs dagböcker, 153.

63 It had been founded in 1924, but had been inactive for years. Ken et al., Shvetsiia, 156.

64 Report from Kollontai to N. N. Krestinskii, August 13, 1936. Here from Ken et al., Shvetsiia, $159-160$.

65 Kan, "Aleksandra Kollontajs privata vänkrets," 274.

66 Ken et al., Shvetsiia, 160-161.

67 Ada Nilsson, “Glimtar ur mitt liv som läkare," Natur \& Kultur (1963): 142-143.

68 Pravda, October 30, 1927.

69 "Kollontay förblev politiskt Stalins mjuka slavinna." Zeth Höglund, Revolutionernas år. 1917-1921, vol. III, (Stockholm: Tidens förlag, 1956), 97. See also different theories about 
As she had done in Norway, Kollontai continued bringing her independent evaluations of political matters to the NKID and even ventured to engage in polemics. She maintained that Sweden (and Scandinavia) was, to a very high degree, influenced by Great Britain. Britain's anti-Soviet position strengthened the same tendency in Sweden. In 1934, Kollontai even doubted whether Sweden would remain neutral in a possible war. The country would bow to Britain's demands. However, Maxim Litvinov, the foreign commissar, found Kollontai's "anti-British pathos" exaggerated. The NKID was more concerned about Sweden's relationship with countries like Poland, Finland and Japan, and feared especially that Sweden could be an instrument of adventurous tendencies in Finnish politics. ${ }^{70}$

Kollontai tried carefully to explain to her superiors the actual facts about the situation in Sweden. For example, in November 1934, the Soviet press ran a negative campaign against Sweden and other Scandinavian countries. It declared that these countries had prepared a hostile policy towards the Soviet Union. The Swedish foreign minister, Rickard Sandler, contacted Kollontai in an attempt to halt the press campaign. Kollontai said she was willing to help with this matter. She told Sandler that she "had been bombarded with reports," but that she did not share the opinion that a hostile policy towards the Soviet Union existed. Her position was forwarded to Moscow, after which the Russian campaign against the Nordic countries was alleviated and, as far as the Scandinavian countries were concerned, ceased. ${ }^{71}$

\section{CONCLUSION}

The Swedish Foreign Office quickly appreciated Kollontai as a diplomat. As early as at the end of 1931, the British minister to Sweden reported that Kollontai "has endeared herself to the Ministry for Foreign Affairs by her correctness in all things, by her abstention from propaganda and by her helpfulness in finding a way out of such difficulties as arise from time to time between the two Governments." 72 Another observer praised Kollontai's patience and

her survival in Ingemar Lindahl, "Alexandra Kollontaj och Norden," in Utrikespolitik och historia. Studier tillägnade Wilhelm M. Carlgren den 6 maj 1987 (Stockholm: Militärhistoriska förlaget, 1987), 158-159.

70 Ken et al., Shvetsiia, 62-67. For Kollontai's comments on England in her diplomatic notes, see, for example, Kollontaj, Aleksandra Kollontajs dagböcker, 265, 275, 412.

71 Lönnroth, Den svenska utrikespolitikens historia, 132-133.

72 Here quoted from Hauge, Alexandra Mikhailovna, 163. 
her ability during difficult negotiations to understand motives and ideas of the opposite party. "She, like few, knew the art of listening - and is this not one of the most important qualities for a good diplomat?"73

In the opinion of some researchers, Soviet diplomatic activity and revolutionary propaganda were tightly fused in the 1920s. They have challenged the theory that there was an institutional dualism that made the NKID the repository of a national interest seemingly removed from any revolutionary implications. ${ }^{74}$ However, in the case of Kollontai, this notion of institutional dualism seems correct. Although she had discussions with party leaders in Norway and Sweden, she obeyed - although grudgingly - Chicherin's order about not meddling in the affairs of the local communist parties. It seems that she left contact with the Comintern to her secretaries. Her reports to the NKID were almost completely free from revolutionary rhetoric. ${ }^{75}$ The impression one gets from Kollontai's diplomatic activity gives no reason for concluding that there was any revolutionary propaganda emanating from the Soviet representations during her time as a polpred.

Kollontai had a great capacity for work and an open mind. She was helpful to the foreign offices in the countries in which she served, and gained respect as a result. She also won respect from the politicians and the broader public, especially in Norway. Compared to the Soviet diplomats in Norway and Sweden before her, and-not least-the Soviet diplomats in Norway after her, she was in another league. Kollontai was always loyal to her country. However, she had an independent mind and did not hesitate to express her own opinion and give advice to her superiors. All things considered, she was an outstanding diplomatic representative of the Soviet Union.

\section{Bibliography}

Büchten, Daniela. "Kunst og politikk. Diplomaten Aleksandra Kollontaj som kulturformidler." In Revolusjon, kjerlighet, diplomati. Aleksandra Kollontaj og Norden, edited by Yngvild Sørbye, 287-316. Oslo: Unipub, 2008.

73 Gunnar Hägglöf, Möte med Europa 1926-1940 (Stockholm: Norstedt, 1971), 122. Hereafter Wahlbäck, "Finland," 172-173.

74 Sabine Dullin, "Understanding Russian and Soviet Foreign Policy from a Geocultural Perspective," Kritika: Explorations in Russian and Eurasian History 12, no. 1 (2011): 177.

75 Holtsmark, “A. M. Kollontaj," 113-114. Admittedly, in November 1924 Kollontai was instructed by Litvinov "to write about party affairs in special reports, and in no way in NKID's general reports." Quoted from Repnevskii, SSSR-Norvegiia, 116. But even before this Kollontai seldom commented on party affairs in her diplomatic correspondence. 
Carlbäck-Isotalo, Helene. Att byta erkännande mot handel. Svensk-ryska förhandlingar 19211924. Uppsala: Studia historica Upsaliensia, 1997.

Celius, Gyrid. "Norwegian-Soviet relations, 1920-1924: Negotiations on the Spitsbergen question and de jure recognition of the Soviet Government." In Caution and Compliance, Norwegian-Russian Diplomatic Relations 1814-2014, edited by Kari Aga Myklebost and Stian Bones, 137-148. Stamsund: Orkana 2012.

Dullin, Sabine. "Understanding Russian and Soviet Foreign Policy from a Geocultural Perspective." Kritika: Explorations in Russian and Eurasian History 12, no. 1 (2011): 177.

Egge, Åsmund. Komintern og krisen i Det norske arbeiderparti. Oslo: Universitetsforlaget, 1995. "Aleksandra Kollontaj og norsk arbeiderbevegelse 1915-1930." In Revolusjon, kjerlighet, diplomati. Aleksandra Kollontaj og Norden, edited by Yngvild Sørbye, 55-81. Oslo: Unipub, 2008.

. "Fra revolusjonsbegeistring til brobygging-Moskva i norsk arbeiderbevegelse 19171991." Mediehistorisk Tidsskrift 28, no. 2 (2017): 16-27.

Egge, Åsmund, and Sven G. Holtsmark. "Soviet Diplomacy and the Norwegian Left, 19211939." In Caution and Compliance. Norwegian-Russian Diplomatic Relations 1814-2014, edited by Kari Aga Myklebost and Stian Bones. Stamsund: Orkana, 2012.

Egge, Åsmund, and Vadim Roginsky, eds., Komintern og Norge, DnA-perioden 1919-1923. En dokumentasjon. Oslo: Unipub, 2006.

Egge, Åsmund and Svend Rybner, eds., Red Star in the North. Communism in the Nordic Countries. Stamsund: Orkana, 2015.

Egge, Åsmund, Sven G. Holtsmark, and Aleksej Komarov. Introduction to Diplomatiske nedtegnelser 1922-1930, by Aleksandra M. Kollontaj, 15-37. Oslo: Res Publica, 2015.

Hauge, Kaare. Alexandra Mikhailovna Kollontai: The Scandinavian Period, 1922-1945. Doct. diss., Minneapolis, MN: University of Minnesota, 1971.

Holtsmark, Sven G., ed. Norge og Sovjetunionen 1917-1955. En utenrikspolitisk dokumentasjon. Oslo: J.W. Cappelens forlag, 1995.

Holtsmark, Sven G. “A.M. Kollontaj og forholdet Norge-Sovjetunionen.” In Revolusjon, kjerlighet, diplomati. Aleksandra Kollontaj og Norden, edited by Yngvild Sørbye, 105-132. Oslo: Unipub, 2008.

Holtsmark, Sven G., ed. Naboer i frykt og forventning. Norge og Russland 1917-2014. Oslo: Pax, 2015.

Hägglöf, Gunnar. Möte med Europa 1926-1940. Stockholm: Norstedt, 1971.

Höglund, Zeth. Revolutionernas år. 1917-1921, vol. III. Stockholm: Tidensförlag, 1956.

Itkina, Anna M. Revoliutsioner, tribun, diplomat. Moscow: Politizdat, 1970.

Kan, Aleksander. Hemmabolsjevikerna. Den svenska socialdemokratin, ryska bolsjeviker och mensjeviker under världskriget och revolutionsåren 1914-1920. Stockholm: Carlsson bokförlag, 2005. "Aleksandra Kollontajs privata vänkrets under de diplomatiska tjänståren i Norge och Sverige." In Revolusjon, kjcrlighet, diplomati. Aleksandra Kollontaj og Norden, edited by Yngvild Sørbye, 253-285. Oslo: Unipub, 2008. 


\section{Part One - The Northern Impact}

Ken, Oleg, Aleksandr Rupasov and Lennart Samuelson. Shvetsiia v politike Moskvy 1930-1950e gody. Moscow: ROSSPEN, 2005.

Kilbom, Karl. I hemligt uppdrag. Ur mitt livs äventyr II. Stockholm: Tiden, 1954.

Kollontaj, Aleksandra. Aleksandra Kollontajs dagböcker 1930-1940. Stockholm: Albert Bonniers förlag, 2008.

Kollontaj, Aleksandra M. Diplomatiske nedtegnelser 1922-1930. Oslo: Respublica, 2015.

Lindahl, Ingemar. "Alexandra Kollontaj och Norden." In Utrikespolitik och historia. Studier tillägnade Wilhelm M. Carlgren den 6 maj 1987. Stockholm: Militärhistoriska Förlaget, 1987.

Lönnrot, Erik. Den svenska utrikespolitikens historia, vol. 5. 1919-1939. Stockholm: P. A. Norstedt \& Söners förlag, 1954.

McDermott, Kevin, and Jeremy Agnew. The Comintern. A History of International Communism from Lenin to Stalin. London: Macmillan, 1996.

Mirnyi, S.M. “Aleksandra Kollontai: kak ia ee pomniu." In Severnaia Evropa. Problemy istorii, vol. 5, Editor-in-Chief O. V. Chernysheva, 292-299. Moscow: Nauka, 2005.

Nag, Martin. Kollontaj i Norge. Oslo: Solum, 1981.

Nilsson, Ada. Glimtar ur mitt liv som läkare. Stockholm: Natur \& Kultur, 1963.

Repnevskii, A. V. SSSR-Norvegiia: Ekonomicheskie otnosheniia mezhvoennogo dvadtsatiletiia. Arkchangelsk: Izdatel'stvo Pomorskogo gosudarstvennogo universiteta, 1998.

Shishkin, V. A. Stanovlenie vneshnei politiki poslerevoliutsionnoi Rossii (1917-1930 gody) i kapitalisticheskii mir. St. Petersburg: Dmitrii Bulanin, 2002.

Sovetsko-Norvezhskie otnosheniia 1917-1955: Sbornik dokumentov. Moscow: ELIA-ART-O, 1997.

Stövling, Britta, ed. Aleksandra Kollontaj: "Kära kamrat: allra käraste vän." Stockholm: Gidlund, 1977.

Sørbye, Yngvild, ed. Revolusjon, kjerlighet, diplomati. Aleksandra Kollontaj og Norden. Oslo: Unipub, 2008.

Wahlbäck, Krister. "Finland—en politisk nervknut. Aleksandra Kollontaj i Sverige 1930-1945.” In Revolusjon, kjcerlighet, diplomati. Aleksandra Kollontaj og Norden, edited by Yngvild Sørbye, 169-208. Oslo: Unipub, 2008.

Åselius, Gunnar. The "Russian Menace" to Sweden. The Belief System of a Small Power Security Élite in the Age of Imperialism. Stockholm: Almqvist \& Wiksell, 1994. 